\title{
EFFECTS OF NEUTRAL SALTS ON HEPATIC MICROSOMAL DRUG-METABOLIZING ENZYME SYSTEM IN RATS
}

\author{
Yoko ANIYA and Kichihiko MATSUSAKI* \\ Laboratory of Pharmacology and Toxicology. School of Health Sciences, \\ University of the Ryukyus. Naha, Okinawa 902, Japan \\ *Miyazaki Medical College, Kiyotake, Miyazaki 889-16, Japan
}

Accepted February 17, 1983

\begin{abstract}
Effects of neutral salts on the drug-metabolizing enzyme system were measured in hepatic microsomes of rats in vitro. Aminopyrine $\mathrm{N}$-demethylation was markedly enhanced by $\mathrm{Li}_{2} \mathrm{SO}_{4}, \mathrm{Na}_{2} \mathrm{SO}_{4}$, and $\mathrm{K}_{2} \mathrm{SO}_{4}$. Salts such as $\mathrm{LiCi}, \mathrm{NaCl}$, and $\mathrm{KCl}$ caused an enhancement of the demethylation following by an inhibition at high concentrations. $\mathrm{KBr}, \mathrm{KI}$, and KSCN always inhibited the demethylation. Aniline hydroxylation, on the contrary, was not stimulated by the sulfates, and all other salts inhibited the hydroxylation with increasing concentration. The effectiveness of the neutral salts on changing aminopyrine or aniline oxidation activity followed Hofmeister's lyotropic series of ions: $\mathrm{SCN}^{-}>\mathrm{I}^{-}$ $\mathrm{Br}^{-}>\mathrm{Cl}^{-}>\mathrm{SO}_{4}^{--}$as anions and $\mathrm{Li}^{+}>\mathrm{Na}^{+}, \mathrm{K}^{+}$as cations. $\mathrm{KSCN}, \mathrm{KI}$ and $\mathrm{KBr}$ caused both the conversion of cytochrome P-450 to cytochrome P-420 and the inhibition of NADPH cytochrome $c$ reductase activity; however, all other salts used in these experiments showed no change of those components. Enhancement of aminopyrine $\mathrm{N}$-demethylation by the sulfates was reversible. It was concluded that cytochrome $P-450$ associated with aminopyrine $\mathrm{N}$-demethylation is different from that of aniline hydroxylation in the hydrophobic environment of microsomes, and sulfate or chloride causes an enhancement of only cytochrome P-450 activity associated with the demethylation.
\end{abstract}

Recently, the isolation of the drugmetabolizing enzyme inhibitor from Habu snake venom has been studied in our laboratory (1). During these studies, the eluent obtained from ion exchange column chromatography was used for evaluating the inhibitory action of drug-metabolizing enzymes of rat hepatic microsomes in vitro. We found that $\mathrm{NaCl}$, which was added to the elution buffer of the chromatography in order to increase ionic strength, tended to stimulate aminopyrine $\mathrm{N}$-demethylation, but tended to inhibit aniline hydroxylation. This finding seems to conflict with the view that neutral salts inactivate microsomal cytochrome P-450 by the conversion to cytochrome $\mathrm{P}-420$ as reported by Imai and Sato (2). Since the existence of multiple forms of cytochrome P-450 has been demonstrated in hepatic microsomes (3-5), it was suggested that neutral salts cause a different action on each cytochrome P-450.

We conducted these studies to clarify the effects of neutral salts on the hepatic microsomal drug-metabolizing enzyme system using various salts in vitro.

\section{Materials and Methods}

Chemicals: Nicotinamide adenine dinucleotide phosphate and glucose- 6 -phosphate were purchased from the Sigma Chemical Co. St. Louis MO; aminopyrine from DaiichiSeiyaku Ltd., Tokyo; glucose-6-phosphate dehydrogenase and reduced nicotinamide adenine dinucleotide phosphate from Oriental Yeast Ltd., Tokyo. Acetylacetone and aniline 
were purified by distillation, and p-aminophenol was purified by sublimation. All other chemicals were of analytical reagent grade.

Preparation of microsomes: Male Wistar rats weighing 150 to $300 \mathrm{~g}$ (from Nihon rat Ltd., Saitama) were used. Animals were fed with a commercial diet (Oriental Yeast Ltd.) and water ad lib. Hepatic microsomes were prepared as follows: The animal was decapitated, and the liver was removed after perfusion with $1.15 \% \mathrm{KCl}$ solution in situ. The liver was homogenized in a teflon-glass homogenizer with 3 vol. of ice-cold $1.15 \%$ $\mathrm{KCl}$ solution. The homogenate was centrifuged at $9.000 \mathrm{~g}$ for $30 \mathrm{~min}$, and the supernatant fraction was further centrifuged at $105.000 \mathrm{~g}$ for $60 \mathrm{~min}$. The resulting microsomal pellet was then resuspended in $1.15 \% \mathrm{KCl}$ solution and used as the microsome preparation. The microsomes were either used immediately or stored at $-20^{\circ} \mathrm{C}$ for two or three days. No effect of storage on the results was observed.

Analytical methods and assay of microsomal components: The reaction mixture for the assay of aminopyrine $\mathrm{N}$-demethylation and aniline hydroxylation contained microsomes (0.5 to $0.7 \mathrm{mg}$ protein). $80 \mathrm{mM}$ Tris- $\mathrm{HCl}$ buffer ( $\mathrm{pH} 7.4)$. NADPH-generating system $10.33 \mathrm{mM}$ NADP, $8 \mathrm{mM}$ glucose-6phosphate, $6 \mathrm{mM} \mathrm{MgCl}_{2}$, and 0.2 units of glucose 6-phosphate dehydrogenase), and $1 \mathrm{mM}$ substrate in a final volume of $1.0 \mathrm{ml}$. When necessary, the salts were added to the mixture. The reaction mixture was incubated in a water bath shaker at $37^{\circ} \mathrm{C}$ under air. The activity of the demethylation of aminopyrine and the hydroxylation of aniline were determined by measuring the formation of formaldehyde and $p$-aminophenol using the Nash method (6) and the method of Brodie and Axelrod (7) as modified by Imai et al. (8), respectively. Cytochrome $\mathrm{P}-450$ and NADPH cytochrome $c$ reductase were measured by the method of Omura and Sato
(9). and the method of Mazel (10), respectively. The difference spectra were determined using a Shimadzu (MPS-50L) spectrophotometer. Microsomal protein was determined by the method of Lowry et al. (11), using bovine serum albumin as the reference protein. All assays and experiments were done at least in duplicate.

\section{Results}

Effects of salts on the activity of aminopyrine $\mathrm{N}$-demethylation and aniline $\mathrm{hy}$ droxylation: The treatment of microsomes with neutral salts caused an enhancement or inhibition of aminopyrine $\mathrm{N}$-demethylation as shown in Fig. 1. The salts such as $\mathrm{Na}_{2} \mathrm{SO}_{4}$

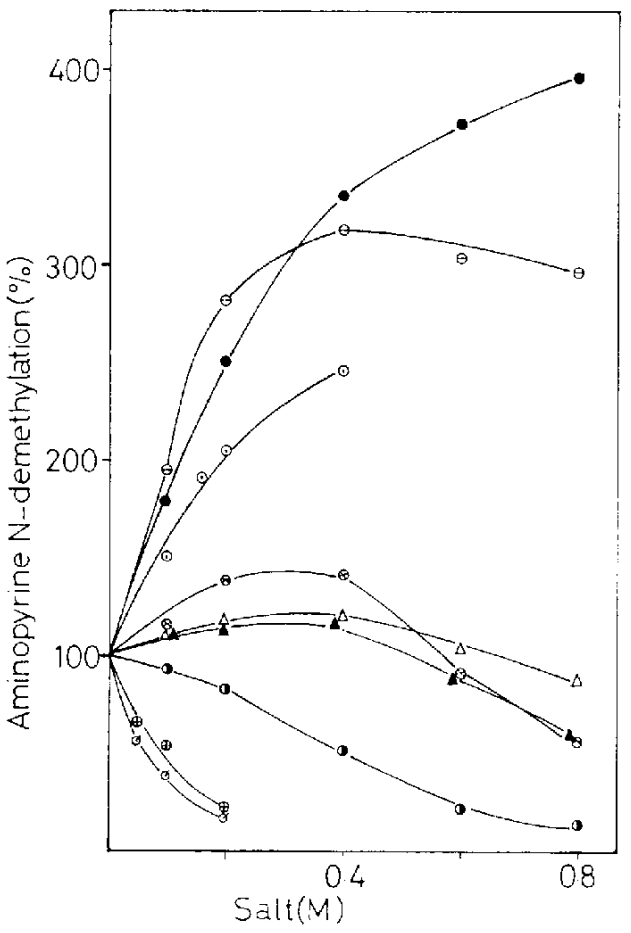

Fig. 1. Effects of salts on aminopyrine N-demethylation. Microsomal aminopyrine $\mathrm{N}$-demethylation activity was measured as described in Materials and Methods using $1 \mathrm{mM}$ aminopyrine and $0.7 \mathrm{mg}$ microsomal protein at $37^{\circ} \mathrm{C}$ for $20 \mathrm{~min}$. Control activity (no salt) was $46.91 \pm 6.80$ nmoles formaldehyde $/ \mathrm{mg}$ protein $/ 20 \mathrm{~min}$. $\mathrm{Na}_{2} \mathrm{SO}_{4}: \mathrm{K}_{2} \mathrm{SO}_{4}: \odot$.

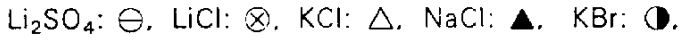
KI: $\oplus . \mathrm{KSCN}: \odot$. 
and $\mathrm{K}_{2} \mathrm{SO}_{4}$ markedly enhanced the aminopyrine $\mathrm{N}$-demethylation with increasing concentrations, and the demethylation activity reached $335 \%$ of the control by $\mathrm{Na}_{2} \mathrm{SO}_{4}$ and $250 \%$ by $\mathrm{K}_{2} \mathrm{SO}_{4}$ at $0.4 \mathrm{M}$. In the case of $\mathrm{Li}_{2} \mathrm{SO}_{4}$, there was marked enhancement of the demethylation, but little increment at concentrations above $0.2 \mathrm{M}$. A biphasic effect on aminopyrine $\mathrm{N}$-demethylation was observed when $\mathrm{LiCl}, \mathrm{NaCl}$, or $\mathrm{KCl}$ was added. These salts enhanced the demethylation at low concentrations, but inhibited it at high concentrations above $0.4 \mathrm{M} . \mathrm{KBr}$ decreased the demethylation activity dose-dependently. $\mathrm{KI}$ and KSCN markedly inhibited the demethylation activity. which was completely lost above $0.2 \mathrm{M}$ of the salts. Some salts at higher concentrations disturbed the color development of formaldehyde, but these effects were all corrected for. The time course of aminopyrine $\mathrm{N}$-demethylation in the presence or absence of salts is presented in Fig. 2. The slope of the curve for aminopyrine

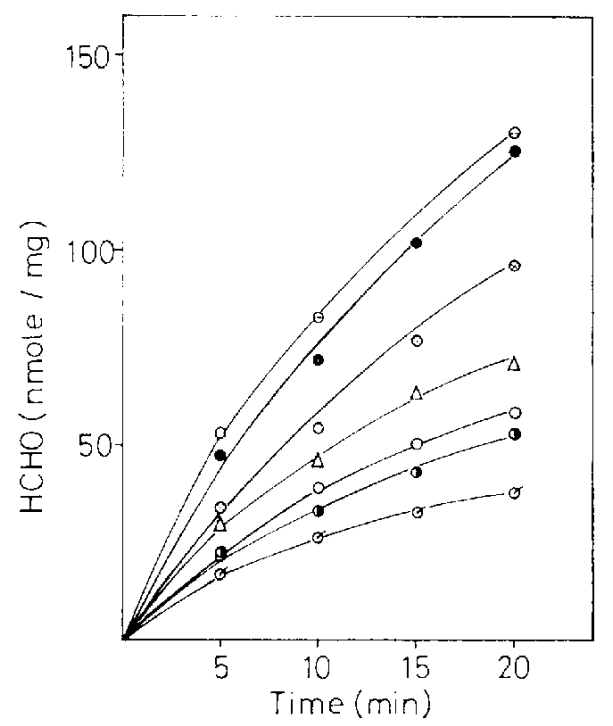

Fig. 2. Time course of aminopyrine $\mathrm{N}$-demethylation. Conditions were the same as described in Fig. 1. All salts were added to the incubation mixture at $0.2 \mathrm{M}$ final concentration, except for $\mathrm{KSCN}$ at $0.05 \mathrm{M} . \mathrm{Na}_{2} \mathrm{SO}_{4}: 0 . \mathrm{Li}_{2} \mathrm{SO}_{4}: \Theta$. LiCl: $\otimes$. $\mathrm{KCl}: \triangle$. Control: $\mathrm{O}, \mathrm{KBr}: \boldsymbol{K S C N}: \circlearrowleft$.
$\mathrm{N}$-demethylation was larger in the case of sulfate or chloride and was smaller in the case of bromide or thiocyanate than that of the contral. Figure 3 shows the effects of salts on aniline hydroxylation. Contrary to the marked enhancement of aminopyrine $\mathrm{N}$ demethylation by the addition of sulfate. little increase of aniline hydroxylation was observed by treatment with sulfate, and the hydroxylation activity was about $112 \%$ of the control even at $0.6 \mathrm{M} \mathrm{Li}_{2} \mathrm{SO}_{4}$. All other salts dose-dependently inhibited the hydroxylation and the order of the inhibition was $\mathrm{KSCN}>\mathrm{KI}>\mathrm{KBr}>\mathrm{NaCl}>\mathrm{KCl}>\mathrm{LiCl}$. This order followed the classical Hofmeister series of ions: $\mathrm{SCN}->\mathrm{I}^{-}>\mathrm{Br}^{-}>\mathrm{Cl}^{-}>\mathrm{SO}_{4}^{--}$as anions (12). This effect of salts on aniline hydroxylation was clarified by observing the time course of aniline hydroxylation.

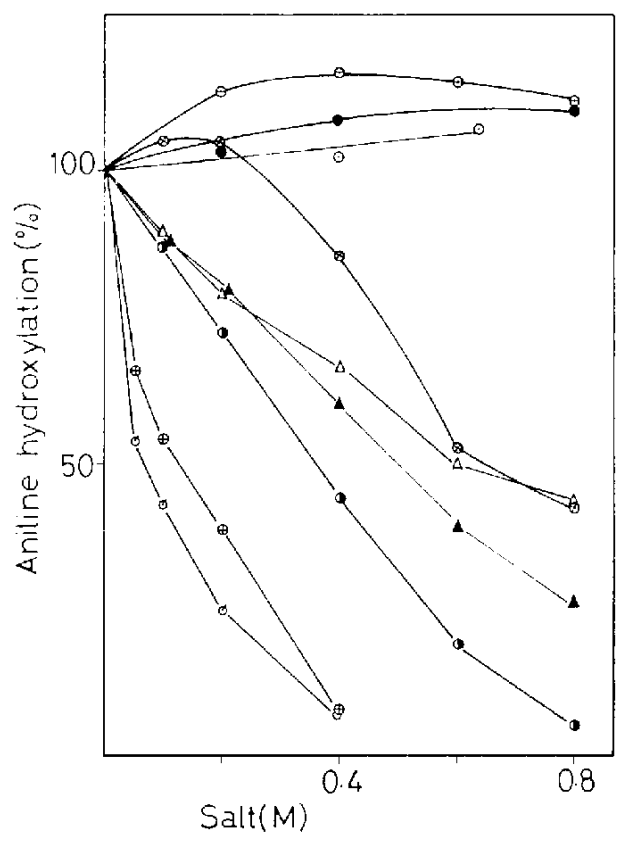

Fig. 3. Effects of salts on aniline hydroxylation. Experimental conditions were the same as described in Fig. 1, except aniline ( $1 \mathrm{mM}$ ) was used as substrate. Control activity (no salt) was 11.01. \pm 0.55 nmoles p-aminophenol/mg protein $/ 20$ min. $\mathrm{Na}_{2} \mathrm{SO}_{4}$ : $\mathrm{K}_{2} \mathrm{SO}_{4}: \odot, \mathrm{Li}_{2} \mathrm{SO}_{4}: \ominus . \mathrm{LiCl}: \otimes, \mathrm{NaCl}: \triangle . \mathrm{KCl}: \triangle$. $\mathrm{KBr}: \circlearrowleft, \mathrm{KI}: \Theta, \mathrm{KSCN}: \boldsymbol{\Theta}$. 


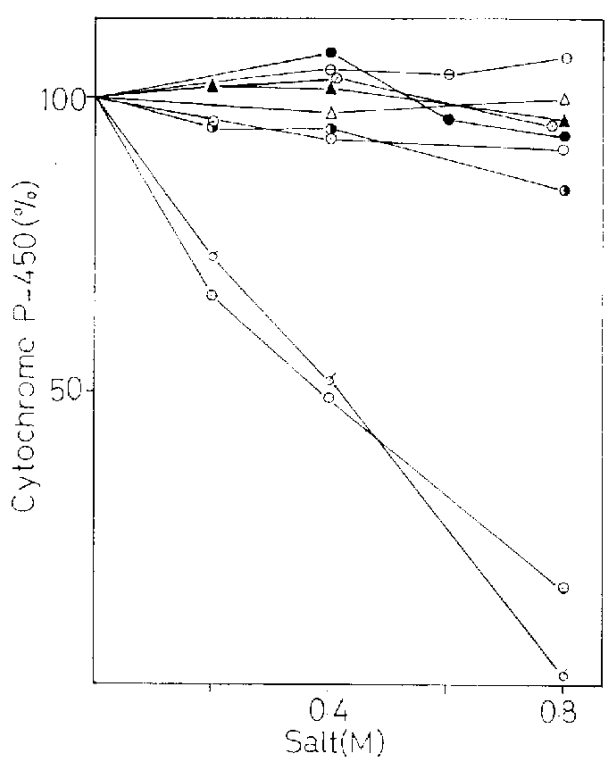

Fig. 4. Effects of salts on cytochrome P-450. Aliquats of $4.8 \mathrm{ml}$ microsomes $(1-2 \mathrm{mg} / 1 \mathrm{ml}$ of $0.1 \mathrm{M}$ phosphate buffer, $\mathrm{pH} 7.4$ ) were incubated with $3.2 \mathrm{ml}$ of various salts at $37^{\circ} \mathrm{C}$ for $20 \mathrm{~min}$. aerobically. The $8 \mathrm{ml}$ reaction mixture was divided into two cuvettes, and then the co-difference spectra of dithionite-treated microsomes were determined by the method of Omura and Sato (9). The control value (no salt) was $0.616 \pm 0.07$ nmoles cytochrome $\mathrm{P}-450 / \mathrm{mg}$ protein. $\mathrm{Na}_{2} \mathrm{SO}_{4}: \mathrm{K}_{2} \mathrm{SO}_{4}$ : ๑. $\mathrm{Li}_{2} \mathrm{SO}_{4}: \Theta, \mathrm{LiCl}: \otimes, \mathrm{KCl}: \triangle, \mathrm{NaCl}: \triangle \mathrm{KBr}: \Theta$ $\mathrm{Kl}: \Theta, \mathrm{KSCN}: \propto$

Effects of salts on cytochrome P-450: Cytochrome $\mathrm{P}-450$ was determined after incubation of microsomes with salts at $37^{\circ} \mathrm{C}$ for $20 \mathrm{~min}$, and the results are shown in Fig. 4. The microsomal cytochrome P-450 content was not significantly changed by incubation with sulfate and chloride. Only $\mathrm{KBr}$ slightly converted cytochrome P-450 to cytochrome $\mathrm{P}-420$ at $0.8 \mathrm{M}$. but almost all the cytochrome $\mathrm{P}-450$ was converted by the same concentration of $\mathrm{KI}$ and $\mathrm{KSCN}$.

Effects of salts on NADPH cytochrome $c$ reductase: Figure 5 shows NADPH cytochrome $c$ reductase activity after incubation with salts at $37^{\circ} \mathrm{C}$ for 20 min. KI and KSCN decreased the reductase activity to $67 \%$ and to $5 \%$ of the control, respectively,

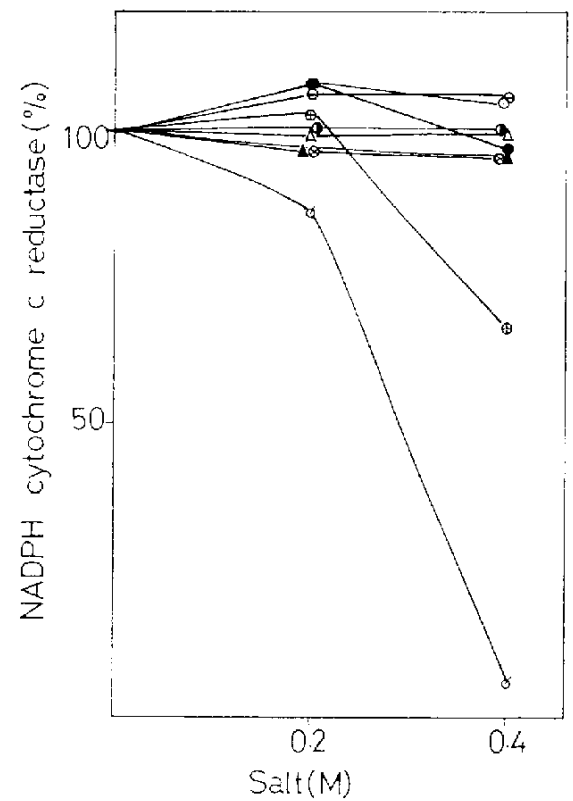

Fig. 5. Effects of salts on NADPH cytochrome $c$ reductase. Aliquots of $1.6 \mathrm{ml}$ microsomes $(0.1-$ $0.2 \mathrm{mg} / 1 \mathrm{ml} 0.1 \mathrm{M}$ phosphate buffer. $\mathrm{pH}$ 7.4) were incubated with $0.4 \mathrm{ml}$ of various salts at $37^{\circ} \mathrm{C}$ for $20 \mathrm{~min}$, aerobically. After incubation. $0.5 \mathrm{ml}$ of the microsomes was used for the determination of NADPY cytochrome $c$ reducatse according to the rnethod of Mazel (10). Control activity (no salt) was $309.23 \pm 92.13$ nmoles cytochrome $c$ reduced $/ \mathrm{mg}$ protein/min. $\mathrm{Na}_{2} \mathrm{SO}_{4}: \bigcirc, \mathrm{K}_{2} \mathrm{SO}_{4}: \odot, \mathrm{Li}_{2} \mathrm{SO}_{4}: \Theta$. $\mathrm{LiCl}: \Theta . \mathrm{KCl}: \triangle . \mathrm{NaCl}: \triangle \mathrm{KBr}:(\mathrm{KI}: \Theta, \mathrm{KSCN}: \varnothing$.

at a concentration of $0.4 \mathrm{M}$. All other salts had no effect on the reductase activity at the same concentration as $\mathrm{KI}$ and $\mathrm{KSCN}$.

Reversible effects of sulfate on the enhancement of aminopyrine $\mathrm{N}$-demethylation: Microsomes were washed by centrifugation after preincubation with $0.4 \mathrm{M} \mathrm{Li}_{2} \mathrm{SO}_{4}$ or $\mathrm{Na}_{2} \mathrm{SO}_{4}$ at $37^{\circ} \mathrm{C}$ for $30 \mathrm{~min}$. Table 1 shows the activity of aminopyrine $\mathrm{N}$-demethylation of washed microsomes in the presence or absence of $0.4 \mathrm{M} \mathrm{Li}_{2} \mathrm{SO}_{4}$. The activity of aminopyrine $\mathrm{N}$-demethylation was increased to $201 \%$ by readdition of $0.4 \mathrm{M} \mathrm{Li}_{2} \mathrm{SO}_{4}$ in control microsomes. In preincubated microsomes with $\mathrm{Li}_{2} \mathrm{SO}_{4}$ and $\mathrm{Na}_{2} \mathrm{SO}_{4}$, the aminopyrine $\mathrm{N}$-demethylation was enhanced to $190 \%$ and to $235 \%$ by the readdition of 
Table 1. Reversible effect of $\mathrm{Li}_{2} \mathrm{SO}_{4}$ and $\mathrm{Na}_{2} \mathrm{SO}_{4}$ on aminopyrine $\mathrm{N}$-demethylation enhancement

Preincubation

Control

$0.4 \mathrm{M} \mathrm{Li}_{2} \mathrm{SO}_{4}$

$0.4 \mathrm{M} \mathrm{Na}_{2} \mathrm{SO}_{4}$
Formaldehyde (nmoles/mg/30 min)

Control

$57.92 \pm 2.19$

$(100 \pm 3.7)$

$62.80 \pm 0$

$(100 \pm 0)$

$62.86 \pm 1.35$

$(100 \pm 2.1)$
Readdition of $\mathrm{Li}_{2} \mathrm{SO}_{4}$

$116.89 \pm 0.95$

$(201.8 \pm 1.6)$

$122.36 \pm 6.44$

$(194.8 \pm 10.25)$

$148.33 \pm 2.38^{*}$

$(235.9 \pm 3.8)$

Preincubation was carried out at $37^{\circ} \mathrm{C}$ for $30 \mathrm{~min}$ in a mixture of the following composition: microsomes $(4.2 \mathrm{mg} / \mathrm{ml}, 1.15 \% \mathrm{KCl}), 0.6 \mathrm{ml} ; 0.2 \mathrm{M}$ Tris- $\mathrm{HCl}$ buffer $(\mathrm{pH} 7.4), 0.9 \mathrm{ml}$; and $\mathrm{H}_{2} \mathrm{O}$ or $\mathrm{Na}_{2} \mathrm{SO}_{4}, \mathrm{Li}_{2} \mathrm{SO}_{4}$ $(0.4 \mathrm{M}$ final concentration) $.1 .5 \mathrm{ml}$. After preincubation, the microsomes were washed by centrifugation at $105,000 \mathrm{~g}$ for $60 \mathrm{~min}$, and resultant pellets were resuspended with the same volume of initial mixture. Aminopyrine $\mathrm{N}$-demethylation activity of washed microsomes was measured as described in Fig. 1 in the presence or absence of $0.4 \mathrm{M} \mathrm{Li}_{2} \mathrm{SO}_{4}$. Values presented are the averagetstandard error of triplicate incubations. ${ }^{*} \mathrm{P}<0.001$ as compared to the control.

$\mathrm{Li}_{2} \mathrm{SO}_{4}$. In the later case, the enhancement of the demethylation was significant. Thus the action of sulfate on enhancing aminopyrine $\mathrm{N}$-demethylation was reversibte.

\section{Discussion}

In studying the effects of neutral salts on the conversion of cytochrome P-450. Imai and Sato (2) showed that the efficiency of various salts in causing conversion of cytochrome P-450 to cytochrome P-420 followed Hofmeister's lyotropic series of ions (12): $\mathrm{SCN}^{-}>\mathrm{I}^{-}>\mathrm{Br}^{-}>\mathrm{Cl}^{-}>\mathrm{SO}_{1}^{--}$as anions and $\mathrm{Li}^{+}>\mathrm{Na}^{+}, \mathrm{K}^{+}$as cations. They explained that the conversion of cytochrome P-450. which was caused by various reagents including neutral salts, resulted from the disturbance of the hydrophobic environment around the heme of the cytochrome P-450. Since cytochrome $\mathrm{P}-420$ is incapable of hydroxylating a substrate (13), it is expected that neutral salts decrease drug-metabolizing enzyme activity in the microsomes. As presented in Figs. 1 and 3, however, neutral salts showed both stimulatory and inhibitory effects on drug-metabolizing enzymes. Aminopyrine $\mathrm{N}$-demethylation was markedly enhanced by sulfate and moderately by chloride. Aniline hydroxylation, on the other hand, was not increased by sulfate; and only inhibition of the hydroxylation was observed by chloride, bromide, iodide, and thiocyanate. The effectiveness of the various ions on altering the activities of aminopyrine $\mathrm{N}$ demethylation and aniline hydroxylation also followed the Hofmeister series of ions. We measured whether the conversion of cytochrome P-450 was caused under the same conditions as for the determination for aminopyrine and aniline oxidation activities. At the maximum concentration of $0.8 \mathrm{M}$ of the salts in our experiments, cytochrome P-450 was almost completely converted to cytochrome $\mathrm{P}-420$ by $\mathrm{KI}$ and $\mathrm{KSCN}$ and slightly converted by $\mathrm{KBr}$, but no conversion of cytochrome P-450 was observed by sulfate and chloride. Concerning the content of cytochrome P-450 and drug-metabolizing enzyme activity, it was demonstrated that aminopyrine $\mathrm{N}$-demethylation and aniline hydroxylation were decreased to $55 \%$ and to $42 \%$ of the control by $0.8 \mathrm{M}$ of $\mathrm{LiCl}$, respectively, in spite of no conversion of the cytochrome P-450. Thus aminopyrine $N$ demethylation and aniline hydroxylation activities were not parallel to the content of 
cytochrome P-450. These results, therefore, show that the oxidative activity of cytochrome P-450 can be changed by neutral salts prior to the conversion of the cytochrome P-450 to cytochrome P-420. The change of oxidative activity in microsomes may possibly come from the alteration of NADPH cytochrome $c$ reductase because the reductase is thought to be the rate-limiting step in the drugmetabolizing enzyme system (14). Our results, however, showed no change of NADPH cytochrome $c$ reductase activity after treatment of microsomes with sulfate and chloride. Hence, it is likely that the enhancement or inhibition of drug-metabolizing enzyme activity by those salts may be due to the effect on cytochrome P-450 itself, but not due to the changing NADPH cytochrome $c$ reductase activity.

There are a number of evidences for existence of multiple forms of cytochrome P-450 which have an overlapping activity for various substrates $(15,16)$. This broad substrate-specificity of cytochrome P-450 is considered to be due to an oily, hydrophobic pocket of cytochrome P-450 which provides a remarkable non-specific substrate binding site (17). On the other hand, aminopyrine and aniline are classified as type I and type II substrates based on the substrate-induced difference spectrum of cytochrome P-450 (18). It is well established that a type I substrate causes spectral change by binding to the hydrophobic region of the cytochrome P-450, and a type II substrate-induced spectrum is due to the interaction of the substrate with the heme iron of the cytochrome (19). Thus the hydrophobic environment of cytochrome $\mathrm{P}-450$ in microsomal membranes is important for aminopyrine $\mathrm{N}$ demethylation. The fact that sulfate or chloride causes a different effect on aminopyrine $\mathrm{N}$-demethylation and aniline hydroxylation suggests that cytochrome P-450 associated with aminopyrine $\mathrm{N}$-demethylation differs from that of aniline hydroxylation in the hydrophobic environment around its active site, and it suggests that these salts alter such a hydrophobic environment resulting in easy entrance of aminopyrine to the active site. These effects by sulfate or chloride may be the stabilization of cytochrome P-450 associated with aminopyrine $\mathrm{N}$-demethylation as presented by von Hippel and Wong who explained that sulfate and phosphate anions can stabilize ribonuclease due to fit and potentiate the iceberg structure which develops around nonpolar residues of the protein in its unfolded form (20). Further study of the enhancement of aminopyrine $\mathrm{N}$-demethylation by sulfate is in progress.

\section{References}

1) Aniya, Y. and Matsusaki, K.: Inhibition of hepatic microsomal drug-metabolizing enzymes by Habu snake (Trimeresurus flavoviridis) vonom fractions. Biochem. Pharmacol. 31, 2039-2046(1982)

2) Imai, $Y$. and Sato, R.: Conversion of $P-450$ to $P-420$ by neutral salts and some other reagents. Eur. J. Biochem. 1. 419-426 (1967)

3) Conney, A.H.: Pharmacological implications of microsomal enzyme induction. Pharmacol. Rev. 19, 317-366 (1967)

4) Welton, A.F. and Aust, S.D.: Multiplicity of cytochrome P-450 heme proteins in rat liver microsomes. Biochem. Biophys. Res. Commun. 56, 898-906 (1974)

5) Gibson, G.G. and Schenkman, J.B.: Purification and properties of cytochrome P-450 obtained from liver microsomes of untreated rats by lauric acid affinity chromatography. J. Biol. Chem. 253, 5957-5963 (1978)

6) Nash, T.: The colorimetric estimation of formaldehyde by means of the Hantzsch reaction. Biochem. J. 55, 416-421 (1953)

7) Brodie, B.B. and Axelrod, J.: The estimation of acetanilide and its metabolic products, aniline. $N$-acetyl p-aminophenol and p-aminophenol (free and total conjugated) in biological fluids and tissues. J. Pharmacol. Exp. Ther. 94, 22-28 (1948)

8) Imai, Y., Ito, A. and Sato, R.: Evidence for biochemically different types of vesicle in the hepatic microsomal fraction. J. Biochem. 60, $417-428(1966)$ 
9) Omura, T. and Sato, R.: The carbon monooxidebinding pigment of liver microsomes. I. Evidence for its hemoprotein nature. J. Biol. Chem. 239, 2370-2378 (1964)

10) Mazel, P.: Microsomal NADPH cytochrome $c$ reductase activity obtained from uritreated and phenobarbital treated rats. In Fundamentals of Drug Metabolism and Drug Disposition. Edited by La Du, B.N., Mandel, H.G. and Way, E.L., p. 544-547. Hirokawa. Tokyo (1974)

11) Lowry, O.H., Rosebrough, N.J., Farr, A.L. and Randall, R.J.: Protein measurement with the Folin phenol reagent. J. Biol. Chem. 193, $265-$ 275 (1951)

12) Hofmeister, F.: Zur Lehre von der Wirking der Salze. Naunyn Schmiedebergs Arch. Exp. Pathol. Pharmak. 24, 247-260 (1888)

13) Imai, $Y$. and Sato, R.: Substrate interaction with hydroxylase system in liver microsomes. Biochem. Biophys. Res. Commun. 22, 620626 (1966)

14) Miwa, G.T., West, S.B. and Lu, A.Y.H.: Studies on the rate-limiting enzyme component in the microsomal monooxygenase system. Incorporation of purified NADPH cytochrome $c$ reductase and cytochrome $\mathrm{P}-450$ into rat liver microsomes. J. Biol. Chem. 253, 1921-1929 (1978)

15) Mannering, G.J.: Significance of stimulation and inhibition of drug metabolism in pharmacological testing. In Selected Pharmacological Testing Methods. Edited by Burger, A., Vol. 3, p. 51-119, Marcel Dekker, New York (1968)

16) Hart, L.G. and Fouts, J.R.: Further studies on the stimulation of hepatic microsomal drug metabolizing enzymes by DDT and its analogs. Naunyn Schmiedebergs Arch. Exp. Pathol. Pharmak. 249, 486-500 (1965)

17) Remmer, H. and Coon, M.J.: The drug metabolizing enzyme system. In Tre Induction of Drug Metabolism. Edited by Estabrook. R.W. and Lindenlaub, E, p. 249-250, F.K. Schattauer Verlag. Stuttgart and New York (1979)

18) Schenkman, J.B., Remmer, H. and Estabrook, R.W.: Spectral studies of drug interaction with hepatic microsomal cytochrome. Mol. Pharmacol. 3, 113-123 (1967)

19) Yoshida, Y. and Kumaoka, H.: Studies on the substrate-induced spectral change of cytochrome P-450 in liver microsomes. J. Biochem. (Tokyo) 78, 455-468 (1975)

20) von Hippel, P.H. and Wong, K.Y.: On the conformational stability of globular proteins. The effects of various clectrolytes on the thermal ribonuclease transition. J. Biol. Chem. 240, 3909-3923 (1965) 